\title{
A Study of S\&T Investment Strength and Development Tendency in Foreign Countries
}

\author{
Feixiang Zhang (Corresponding author) \\ Business School, University of Shanghai for S\&T, Shanghai 200093, China \\ E-mail: zhangfx2000@msn.com \\ Jingliang Chen \\ Business School, University of Shanghai for S\&T \\ Shanghai 200093, China
}

Received: March 2, 2011 Accepted: March 18, 2011 doi:10.5430/ijba.v2n2p149

\begin{abstract}
Based on the examination of the "Research and Development (R \& D) Funds", an important indicator of S\&T investment, this paper made an in depth study of S\&T investment in foreign countries at different industrial stages of evolution, the positioning of and relationship between government and enterprises in investment, and the effects of government funded enterprises' $R \& D$. Thus, the tenets of $S \& T$ investment in foreign countries are grasped and its develop trend is fathomed to provide us some inspirations for the S\&T investment in China.
\end{abstract}

Keywords: S\&T investment, R\&D, Development Tendency

\section{Definition of S\&T Investment Strength}

United Nations Educational, Scientific, and Cultural Organization (UNESCO) and most countries in the world use the "Research and Development (R \& D) Funds" as an important indicator of S\&T investment. The proportion of R \& D Funds in Gross Domestic Product (GDP) is a set of important indicator internationally applied to measure the size of national S\&T campaigns and the strength of S\&T investment, and to some extent, reflect the country's potential of economic growth and the capability of sustainable development.

\section{Different Stages of S\&T Investment Strength}

\subsection{Three stages of $R \& D$ investment and industrialization}

The industrialization experiences of developed countries have shown that technical innovation is closely linked to the different stages of industrialization. According to the theory of development economics, industrialization can be divided into three stages:

The first stage: initial stage of economic growth with a per capita GDP of less than $\$ 400$. The R \& D investment strength in this stage is relatively low (R\&D GDP ratio is lower than $0.8 \%-1 \%$ ), and grows at a tardy pace. Those countries with a R\&D of between $0.6 \%$ and $1 \%$ are developing countries.

The second stage: economic surging period with a per capita GDP of $\$ 400-\$ 2100$, in which S\&T is most highly demanded. The S\&T investment intensity is also increasing at the fastest speed in this period, normally overtaking economic growth rate; R\&D GDP ratio grows most dramatically. (1\% -2\%) This period lasts for about a decade. Overall, China is in the period of rapid industrialization, yet the task of industrialization is far from complete. The level of per capita GDP is still ranking behind, rendering itself a low-income developing country.

The third stage: developed economy with considerably stable growth and per capita GDP of over $\$ 2100$. At this stage technology investment intensity has reached a high level, S\&T investment growth is slowed or in fluctuation, and the R\&D GDP ratio in developed countries will generally climb to around $3 \%$ or more. When per capita GDP reaches $\$ 2100$ - $\$ 3360$, initial stage of developed economy is achieved; when per capita GDP ranges from $\$ 3360$ to $\$ 5040$, an advanced stage of developed economy begins. This indicator has a theoretical feasibility and pragmatic comparability. According to the correspondence curve between national economic development stages (developing, industrialization and developed) and the R \& D GDP ratio, when the latter reaches $1.5 \%$, it more or less indicates that the country is at the doorstep of industrialization.(table1) 


\subsection{R\&D input ratio in these three stages}

The investment intensity in those core innovative countries, such as U.S., Japan, and Germany, are basically the same in the three aspects of basic Research, applied study, as well as testing and development, which are distributed at the proportion of 1:2:5. In another word, the investment strength of basic research takes up $12 \%-15 \%$, applied research, $25 \%$, testing and development, $60 \%-63 \%$. Basic research funds from OECD countries account for over $20 \%$ of averaged R \& D (Research and Experimental Development) funds.

\section{Positioning of and Relationship between Government and Enterprises in S\&T Investment}

\subsection{S\&T Investment Ratio of the Government and Enterprises}

At different stages of industrialization, the investment structure of S\&T will change accordingly. In the first and second phase of industrialization, government plays a leading role in S\&T investment for enterprises' inferior capacity of technology innovation investment renders itself unable to assume the responsibility of a major investor. In most countries, government S\&T investment takes up over $50 \%$ of the total input. After per capita GDP reached $\$ 4,000$ dollars, the enterprise technology investment will exceed the Government Technology Investment thus embracing the transition period form the final stage of developing country to a developed country. As a major practitioner of S\&T, enterprises' position as a major investor is not revealed until final stages of industrialization. In respect of sources of R \& D funds in the whole society, government funds accounts for about $40 \%$ of the general, while corporate share of R \& D funds increases gradually, and the ratio between government and corporate R \& D funds remained at 35:60. It should be noted that, at different stages of industrialization, the scale of government investment in basic research (measured by the proportion of basic research fund in total R \& D investment) has remained relatively stable, no much difference across countries. The United States, Japan, and South Korea remained at 13\%-17\%, and France and Germany about 20\%, indicating that,) as a source of innovation, basic research has its own development law.

\subsection{Research on Enterprise Investment in $S \& T$}

Based on theories and practices, a ratio of S\&T investment over sales revenue is used overseas to measure corporate S\&T investment strength. The research results are: enterprises with a R \& D funds taking up $1 \%$ of Sales Revenue is difficult to survive, $2 \%$ is maintainable, over $5 \%$ is competitive, and the figure in high-tech areas is $8 \%-15 \%$.

\subsection{Effects of Government-Funded $R \& D$ on an Enterprise}

\subsubsection{Effects of varying subsidizing policy tools}

OECD research shows that government direct funding R\&D executed by enterprises exerts encouraging effects on corporate R\&D. Every yuan government subsidize the corporate can produce 1.7 yuan of R\&D investment. Direct government funding and tax incentives are interchangeable, and to increase the strength of one policy tool means reducing the effects of another, however, the effects of direct government funding will last longer than that of tax incentives, reflecting that the time range for research projects set by the government is longer than that set in the corporate agenda.

\subsubsection{Impact of government funding scale on its effect}

OECD research indicates that the government-funded share in corporate $\mathrm{R} \& \mathrm{D}$ investment and its effect is of an inverted U-function relationship, in which if the proportion reaches a certain value, the incentive effects will come to the maximum; when it exceeds certain amount, it will generate "Crowding-Out Effect", and the value of these two proportions perform differently in long-term and short-term impacts (Figure 2-1). Thus, "Crowding-Out Effect" under the government's funding does exist, and the "Crowding-Out Effect", however, can be eliminated to some extent if the financial funding to corporate R \& D maintains at an appropriate scale. Figure1 shows, if the proportion of government subsidy reach about $15 \%$, the incentive effect of short term impact should reach its peak, while the long-term impact is about $20 \%$, indicating the impact of subsidy policy has a significant time delay. Taking both Short-term and long-term effects into account, we can see that the mid-high subsidy scale(11\%-19\%) will create maximum incentive effects. Medium and small funding, particularly the small-scale, will help to fuel incentives into local enterprises R \& D investment, while large-scale funding exerts lower incentive and is prone to create "Crowding-Out Effect". But for multinational companies, the scale of government-funded has practically no impact on corporate R\&D investment.

\subsubsection{Impact of stability of government funding policies on its effect}

H. Capron, Van Pottelsbergue used the standard deviation of annual growth rate of the R \& D funds (Government R \& D investment / total R \& D investment) in the Seven Western Countries from 1973 to1990 as the Volatile variables of funding policy, to analyze the impact of stability of government funding policies on its effect. It turned out that the more stable subsidizing policy is, the better its effects. The wilder funding proportion changes, the less undesirable its effects are. However, these effects differ in different countries. 
The effect of enterprise's technology exclusiveness on government funding. The exclusiveness of an enterprise's technology has a significant impact on government funding. In enterprises with less exclusive technology, government funds have higher incentives, while in those with more exclusive technology, the incentives are not evident and Crowding-out effect is likely to appear. Therefore, the government funding should focus on those areas with less exclusive technology. That is corporate technology innovation campaign with more technology spillover, mainly including basic and applied research, generic technology research, reducing the funds in enterprise R \& D activities to the market. As for the funding recipients, enterprise R\&D cooperation organization with less exclusiveness should be given more support to promote their formation of their R \& D network structure and diffusion of new technologies.

\section{The Trend of Investment in S\&T in Foreign Countries}

\subsection{Government investment in $S \& T$ should be increased considerably to protect the national innovation capacity}

To enhance our competitiveness and secure a seat among the high-tech powerhouse in the world, those governments, particularly in developed countries, have increased their R \& D expense rapidly in recent years. From 2000 to 2002, Government's R \& D spending in OECD countries increased from $0.63 \%$ of GDP to $0.68 \%$, especially in the United States, Japan and the European Union. At the same time, in most OECD countries, we see a substantial increase in government R \& D budget. 1 / 3 of the countries have an average annual growth rate of above 5\% from 1995 to 2003 . Among which the U.S. government R \& D budget rose by 44\% from $\$ 910$ billions in fiscal year 2001 to $\$ 132$ billions in the fiscal year 2005, which is a record high. The average annual increase is more than $10 \%$. India's new government increased its R \& D budget remarkably in 2004, by almost 1 / 4 compared with 2003, to 152 billion rupees (about $\$ 3.3$ billions), almost all major projects received $15 \%$ more fund.

4.2 The Government should clarify areas and priorities of its $S \& T$ investment, reflecting the strategic objectives of national development.

Just as U.S. president S\&T adviser Marburger said, research funding "gap" is always there. Therefore, while Governments' R \& D investment increased year by year, it's far from enough to meet the economy society targets. Prioritization according to national circumstances and focus R\&D fund on some key strategic areas is of vital importance. To the purpose of taking full advantage of the limited financing, governments should "sometimes get involved, sometimes stand back" and concentrate funds for the carry-out of research and development in prioritized strategic areas. (1) United States: stresses on taking a comprehensive lead in all scientific frontiers. (2) Germany: emphasizes on the development of cutting-edge technology, identified four investment objectives: origination and innovation, balanced national development, high-tech leader, and cutting-edge technology. (3) Japan: emphasizes on development of industrial generic technology, expecting to cultivate about 30 Nobel Prize winners within 50 years. (4) South Korea: emphasizes on development of industrial generic technology, its target is to become the major research centers in Asia-Pacific region by 2015, ensuring its S\&T competitiveness comparable with G7. (5) India and Brazil stressed on local leadership, money goes primarily to industry.

The main areas of governments' S\&T investment: (1) basic research and those related to capacity-building of self-sustained innovation has become priority areas for government investment in S\&T. Basic research takes up over $10 \%$ of government S\&T investment. (2) Social welfares such as sanitation, health, and environment should be the priority of government S\&T investment. (3) Technology infrastructure calls for ever-increasing government S\&T investment (4) The Government supports a more goal-oriented industrial technology research, supporting efforts also being increased. (5) the implementation of strategic product plan is becoming an important means to achieve technology integration for many countries and is also a key areas of government S\&T investment.

4.3 To implement the scientific management system of "top-level design, overall planning" improve the efficiency of innovation investments

Government Technology Investment Strategy is of vital importance to economic growth, social development and national security, therefore, many countries tend to take relatively centralized management model that is unified and coordinated policy to co-ordinate the allocation of resources and centralize management budget. For example, France and Germany are taking a unified and coordinated management system for S\&T investment with scientific and technological department, which plays a leading role in the management of technology budget, controlling and regulating $2 / 3$ of the Government S\&T budgets. In order to improve the efficiency of public funds, Japan, Korea, Australia conducted a reform of S\&T management system. In 2001 Japan established a S\&T Conference led directly by the Prime Minister, the Ministry of Education set an unified S\&T policy based on the comprehensive strategic approach to technology. After the Asian financial crisis, Korea Technology Investment System has been adjusted, the National R $\&$ D management system made a transition from the formerly distributed one to the current integrated one, and set up a 
"State S\&T Committee" led by the President as the chairman, taking responsibility for coordinating technology policy, approving S\&T budget and examining the prioritized development areas, so as to enhance the authority of top-level design and management coordination of S\&T investment strategy. The funds hold by S\&T management departments in some OECD countries take up over $50 \%$ of the total domestic R \& D investment.

\subsection{Public research institutions have gradually increased the proportion of competitive project funding, and emphasized} on performance evaluation

In OECD countries, subvention system of the public research institutions and its allocation mechanism of funds have two major changes in trend: First is to link institutional funding with evaluation mechanisms. The reason for institutional findings' emphasis on efficiency is to form an incentive mechanism for the public research institutions and to improve the overall performance of public investment in S\&T. And as research fund is getting closer to the social needs, evaluation begins to take into account research level and practicality. However, there is still need for further study accordingly. Second, the proportion of competitive project funding is rising. Institutional funding and project-based funding are widely applied public funding systems around the world. The former is goal-oriented and stable and has obvious advantages in the accumulation of knowledge and sustainable development, while the project-based fund highlights efficiency. With greater efficiency requirements, some countries have increased the proportion of project funding.

Table 2 shows development trends of in institutional funding and Competitive funding in some of the OECD countries. In those dual economy countries, overall public research budget is usually allocated to different levels of government and different departments. When the different government departments support their relevant research institutions, financial support favors competitive project support mode. The introduction of competitive funding mechanism is to promote the interaction between government research institutions and enterprises. In Germany, demand for enterprise organizations to promote the correlation between government research institutions and enterprises. In Germany, in order to lead the institution to corporate needs and improve the quality of their research, Helmholtz Research Centre's institutional funding mode is being replaced by some competitive funding modes. Even those institutions engaged in basic research such as the French National Scientific Research Center and the Max Planck Institute in Germany were also implementing relevant reforms to maintain their basic research capacity, and meanwhile, cooperate with enterprises. However, the increase in the proportion of project-based funding was more reflected in the elevation of government R \& D investment. It does not indicate reducing original institutional funds which remain unchanged and are mainly used for salaries and indirect costs (for management and operation of research institutions), and basic research projects.

At the same time, in order to improve the research level of universities and public institutions, OECD countries have reformed those research institutions in public sector. First is the centralized management of government research institutions. More fundamental reform is to implement the privatization of government institutions, making them "devolved" institution or private entity. But in the process of restructuring, public features of research institutions must been taken into full account. For example, in the privatization wave in Britain, those public research institutions with prominent public functions, such as the Ministry of Health research institutions, were not privatized.

\section{References}

Bai Jingming (2004). To Building a Performance Evaluation System suitable for the China Financial Investment in S\&T [J]. Beijing:Chinese Financial Information, 2004:2-5.

Liu Lei, Hu Shuhua (2003). Comparison of domestic and foreign R \& D management research and technological resources of inspiration in China [J]. Beijing:Studies in Science of Science, 18 (1).

Liu Youping (2005). United States, Japan, Germany and Korea Comparative Technology Resource Allocation Model and Its Significance [J]. Haerbin:Science Technology and Management, (5).

Wang Tao, Li Shizhu (2002). The context of the main analysis ways of the allocation of resources of government-led technology in the international context [J]. Beijing: Forum of Science Technology in China, 2002 (2). 
Table 1. R\&D investment and the three stages of industrialization

\begin{tabular}{|c|c|c|c|c|c|c|}
\hline & \multirow{2}{*}{$\begin{array}{c}\text { per capita } \\
\text { GDP(dollar) }\end{array}$} & \multirow{2}{*}{$\begin{array}{l}\text { R\&D/GDP } \\
\text { Ratio(\%) }\end{array}$} & \multirow{2}{*}{$\begin{array}{l}\text { Stages of } \\
\text { economic } \\
\text { growth }\end{array}$} & \multirow{2}{*}{$\begin{array}{l}\text { R\&D Input } \\
\text { Model }\end{array}$} & \multicolumn{2}{|c|}{ Innovative stage } \\
\hline & & & & & $\begin{array}{c}\text { per capita } \\
\text { GDP }\end{array}$ & $\begin{array}{c}\text { Specific } \\
\text { stage }\end{array}$ \\
\hline $\begin{array}{l}\text { The first stage } \\
\text { of } \\
\text { industrialization }\end{array}$ & Below $\$ 400$ & $\begin{array}{c}\text { Below } \\
0.8 \%-1 \%\end{array}$ & $\begin{array}{c}\text { The initial stage } \\
\text { of economic } \\
\text { growth }\end{array}$ & $\begin{array}{c}\text { Government } \\
\text { dominated }\end{array}$ & $\begin{array}{l}\text { Below } \\
\$ 1,000\end{array}$ & $\begin{array}{l}\text { Technology } \\
\text { introduction } \\
\text { and copy }\end{array}$ \\
\hline $\begin{array}{l}\text { The second } \\
\text { stage of } \\
\text { industrialization }\end{array}$ & $\$ 400-2,100$ & $1 \%-2 \%$ & $\begin{array}{c}\text { The economic } \\
\text { surging/booming }\end{array}$ & $\begin{array}{c}\text { Government \& } \\
\text { enterprises } \\
\text { dual-domination }\end{array}$ & Above $\$ 1,000$ & $\begin{array}{l}\text { Digestion, } \\
\text { absorption } \\
\text { and } \\
\text { upgrading } \\
\text { innovation }\end{array}$ \\
\hline $\begin{array}{l}\text { The third stage } \\
\text { of } \\
\text { industrialization }\end{array}$ & $\begin{array}{l}\$ 2,100-3,360 \\
\$ 3,360-5,040\end{array}$ & Above $2 \%$ & $\begin{array}{l}\text { The initial stage } \\
\text { of the developed } \\
\text { economies; } \\
\text { the advanced } \\
\text { stage of the } \\
\text { developed } \\
\text { economies }\end{array}$ & $\begin{array}{c}\text { Enterprises } \\
\text { dominated }\end{array}$ & Above $\$ 5,000$ & $\begin{array}{l}\text { self-sustained } \\
\text { innovation }\end{array}$ \\
\hline
\end{tabular}

\section{Three stages of R\&D investment and industrialization}

Table 2. Development trends of institutional funding and Competitive funding in some OECD countries (unit :\%)

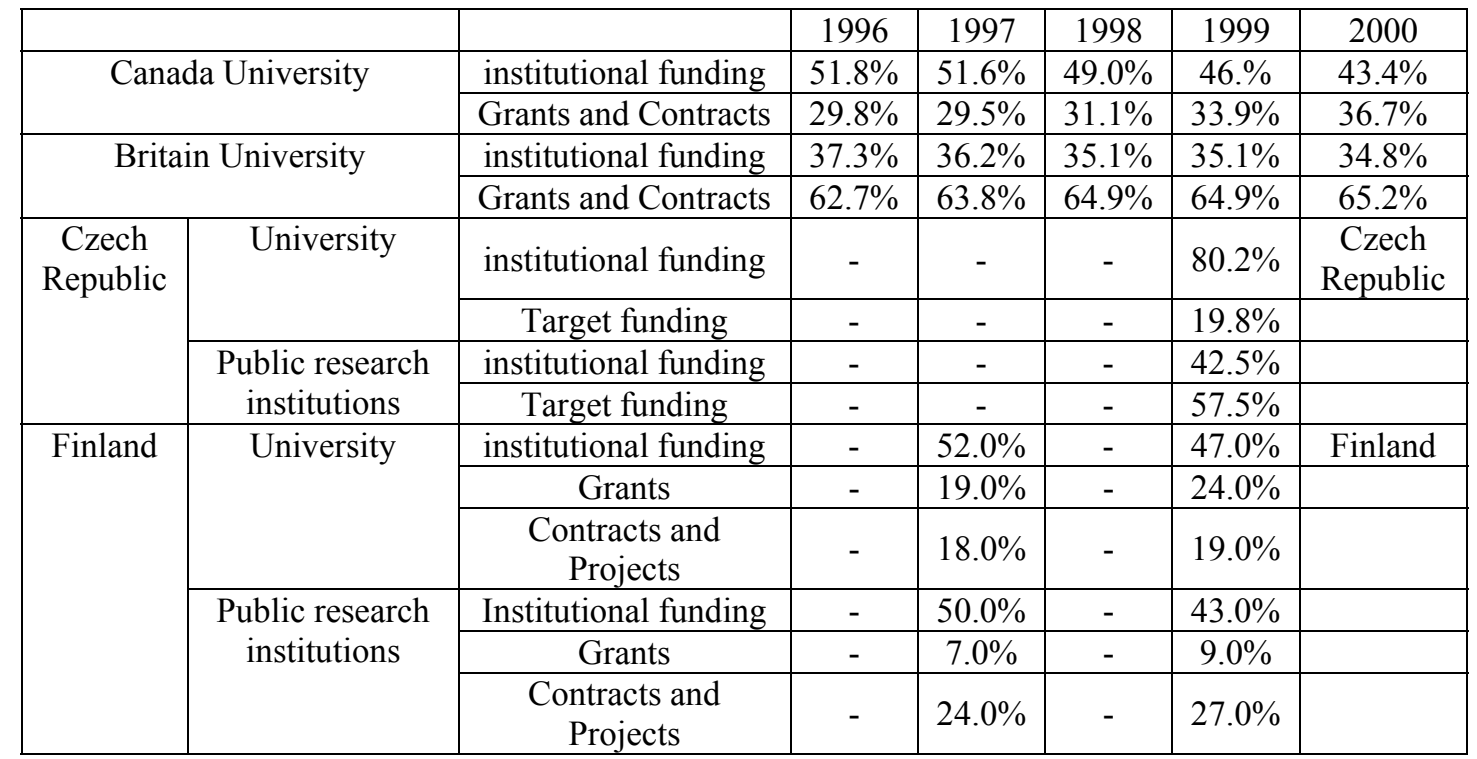

Sources: Governance of Public Research: Toward Better Practice. OECD.2003. 


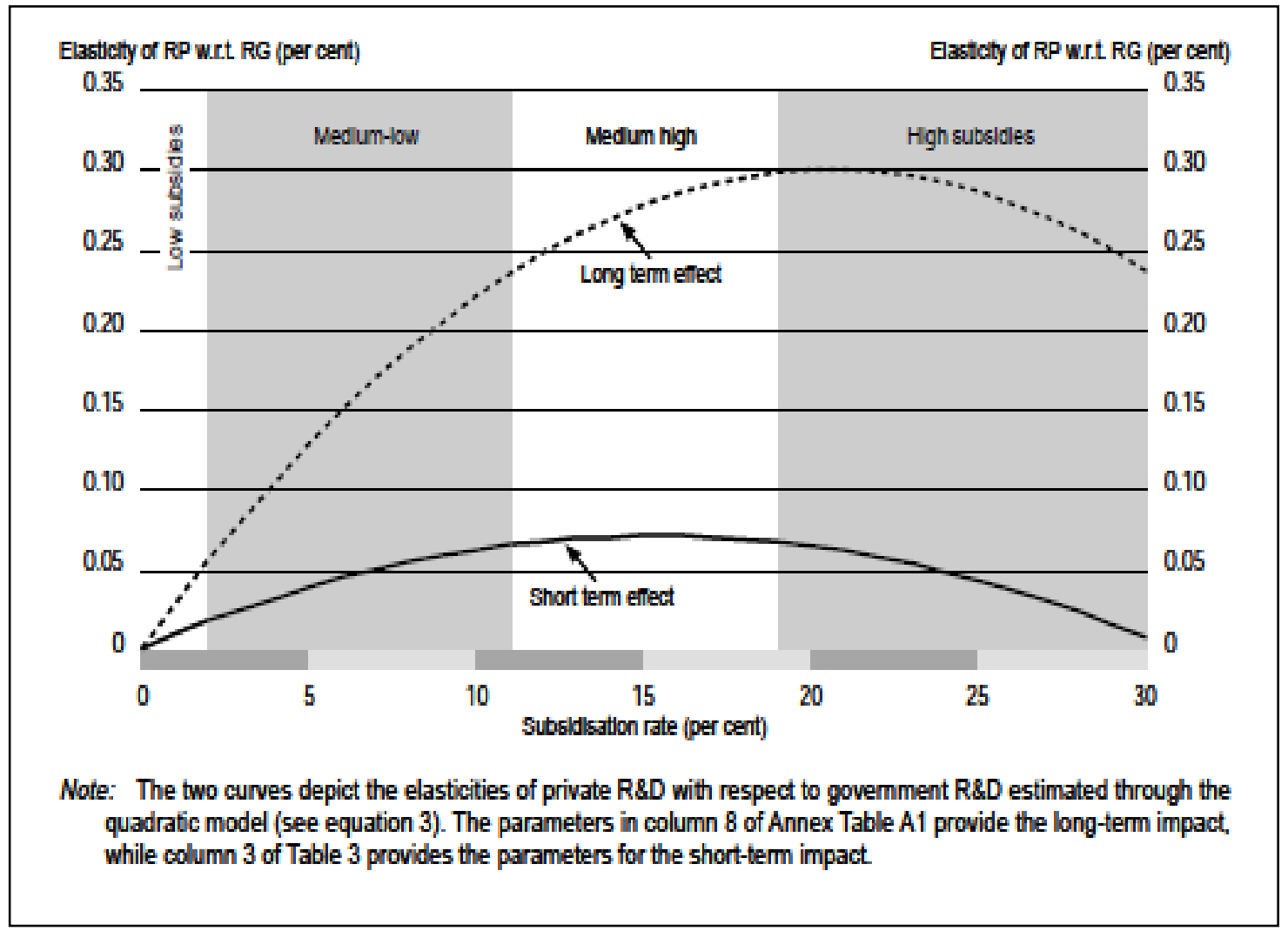

Figure 1. Estimated elasticity of private R\&D with respect to government subsidies and its dependence on the initial level of subsidy

Source: Dominique Guellec, Bruno van Pottelsberghe de la Potterie. Does government support stimulate private R\&D? Jointly with D. Guellec, OECD Economic Studies, 29,1999 